\title{
R. C. Horwitz
}

\section{DISCUSSION ON :}

\section{A progress review of the Hamersley Basin of Western Australia.}

\author{
by
}

A. F. Trendall

(Bulletin of the Geological Survey of Finland 307, 1980).

R. C. Horwitz (CSIRO, Institute of Earth Resources, Wembley, W.A.

6014, Australia).

Sir,

In his paper "A progress review of the Hamersley Basin of Western Australia», Dr. Trendall (1980, p. 113) aims to provide readers with the knowledge of "which aspects of earlier accounts may have been superseded" as well as "provide a brief guide to the existing literature, particularly for geologists working on the Baltic Shield who may not have ready access to Australian publications». It is with similar directives that I am submitting this discussion of his paper.

Horwitz \& Smith (1978) published results indicating that the Hamersley Group was deposited on a submerged shelf, not in a basin outlined more or less by the present outcrop. The shelf was formed on the underlying. Fortescue Group rocks which do not thicken in the centre of a basin. In particular, we envisaged that the Archaean substratum was domed and that there was no shore-line, for either the Fortescue or Hamersley groups, to the southwest against the area now occupied by the Ashburton (Wyloo) Trough. Contrary to references by Trendall (op. cit. p. 128), these results are independent of the correlation of the Hamersley Basin units with those of the Nabberu Basin.

The following evidence is submitted in support of our proposal that the distribution of facies and the thickness patterns agree with our model rather than that of a simple basin. The concept of a shelf environment could modify views on the genesis of banded-iron formations in the Precambrian.

\section{Fortescue Group}

Horwitz and Smith (1978, p. 308) have discarded the frequently quoted hypothesis (Trendall, p. 116) that the Fortescue Group developed first over Archaean greenstones whilst the granites formed positive areas on the surface of unconformity. This hypothesis was established for the region around the Mt. Edgar Batholith and Point Samson areas of the Pilbara but the many exceptions, such as the areas south of Western Shaw or at Mt. Leopold (see Hickman, 1980) indicate that the idea cannot be generalised. The opposite interpretation, that greenstones formed the positive areas of the unconformity, could be deduced from de la Hunty's (1969) mapping between Jimblebar and the Opthalmia Range, about $50 \mathrm{~km}$ east of Newman. However, Horwitz and Smith (op. cit.) have shown (in particular Figs. 5, 6 and 7; and pp. 308 to 310 and 314) that the compilation of places of abutment and overlaps indicate a simpler pattern: During deposition of the Mount Bruce Supergroup, transgression and progradation resulted in the overlapping onto a broad basement ridge, or geanticline, which was plunging to the northwest and which tilted, or subsided faster, towards the south- 


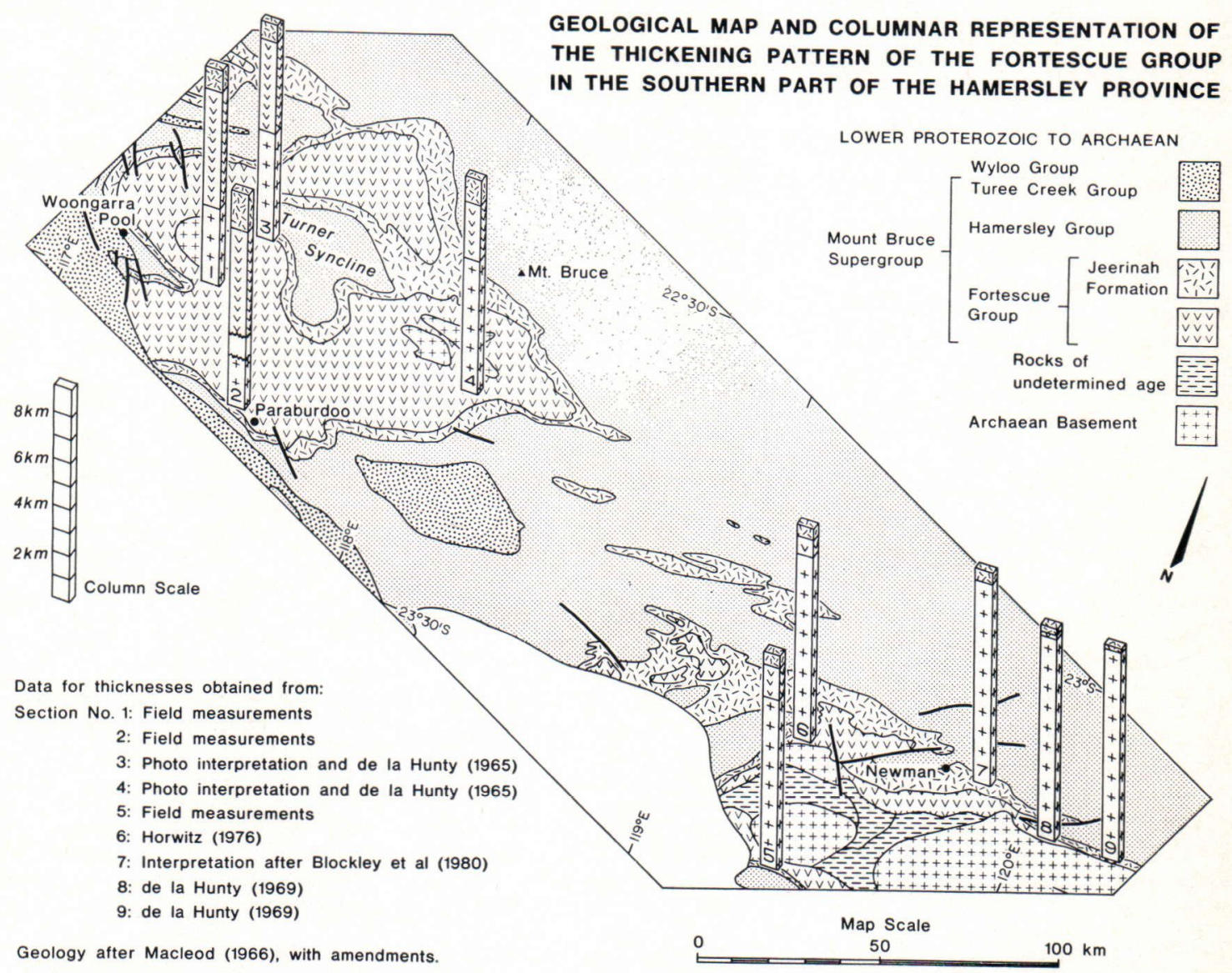

Fig. 1.

west already during sedimentation of the Fortescue Group. This tilt is towards Fraser's (1976) Ashburton Regional Gravity Ridge area, which coincides with the Ashburton (Wyloo) Trough area, between the substratum of the Pilbara Block, in the North, and the Yilgarn Block and the Gascoyne Metamorphic Province to the South (Horwitz \& Smith, op. cit. Figs. 1 and 4). This was concluded from a model, based on columnar sections, measured throughout the Hamersley Province. Figure 1 shows, that near Newman this process of overlap onto a basement-high persisted even during the deposition of the Jeerinah Formation, the upper unit of the Fortescue Group. It also shows how, according to our data, the Fortescue Group thickens to the southwest from the Turner Syncline area, as well as in the Newman area (already discussed in Horwitz, 1976).

The tilt of the substratum was deduced from paleogeological sections (op. cit. Fig. 6) and agrees with the distribution of dominant subaqueous facies mentioned by Trendall (p. 116) in the upper half of the Fortescue Group; the feature of this part of the sequence is a facies of pillow lavas associated with coarse tuffs, present throughout the southwestern (deeper) part of the shelf (see de la Hunty, 1965; Daniels, 1968, 1970; Horwitz, 1978).

\section{Hamersley Group}

It is considered significant that stromatolitic carbonates in the Hamersley Group are 


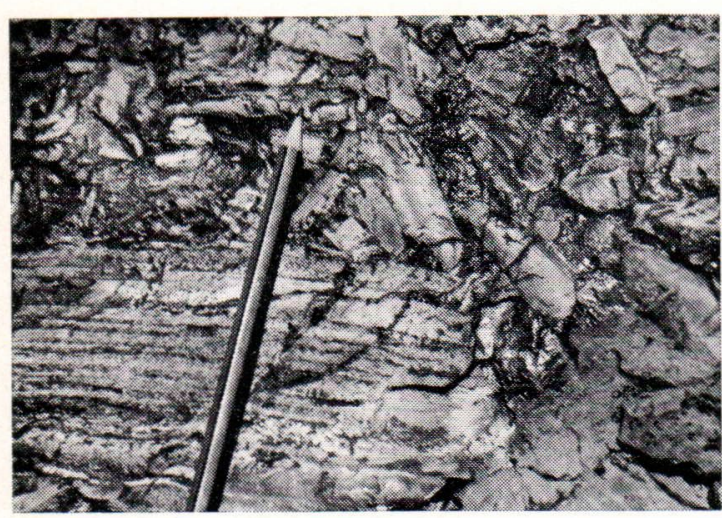

Fig. 2. Breccia at the top of macroband $\mathrm{S}_{3}$, Dales Gorge Member, west bank Beasley River Section.

only recorded from the eastern part in the Carawine Dolomite, (equated to the Wittenoom Dolomite, de la Hunty, 1964). A $21 \mathrm{~m}$. thick feldspathic sandstone is recorded in the Mt. Sylvia Formation at Newman (Anonymous, 1975) (compare to Fig. 1), but otherwise, nowhere westwards have shore line facies been recorded in the Hamersley Group which, with the exception of the Wyloo Anticline region (125 km west of the Turner Syncline, discussed by Horwitz, 1978) and the eastern margin of exposures (see Trendall \& Blockley, 1970, Fig. 2) is relatively even in thickness and persistent throughout. Isopachs are published for the Dales Gorge Member only (Trendall \& Blockley, 1970 pl. 3). Excluding the southwest corner, their data indicate a relatively simple pattern, exemplified by a section starting at Paraburdoo, in the south (135 m. approx. thickness), to $100 \mathrm{~km}$ northeast, near Mt. Bruce (about $165 \mathrm{~m}$. thick), to the type section (142 m. in thickness) some $40 \mathrm{~km}$ further northeast. Bourn \& Jackson (1979, p. 190), and more recently Ewers \& Morris (in press) indicated that near Paraburdoo, BIF (banded cherty iron formation) macroband thicknesses are comparable with those of the type section and the thinning is reflected in the intervening $\mathrm{S}$ (shale, chert and siderite) bands. The steeper gradients of the southwest in the Dales Gorge Member isopach map are largely due to measure-

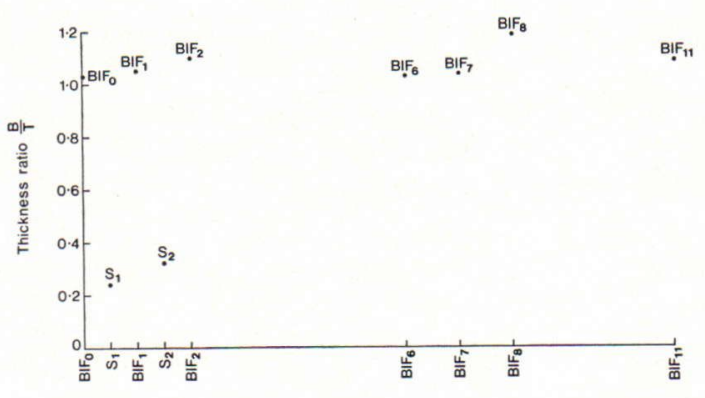

Fig. 3. The thickness of some macrobands between $\mathrm{BIF}_{0}$ and $\mathrm{BIF}_{11}$ of the Dales George Member, at the Beasley River Section (B) relative to that of corresponding bands at the Type Section of Trendall and Blockley (1968) (T).

ments in the Beasley River Gorge section, near Woongarra Pool. There, accurate measurements can only be made in the valley side, between the river bed and disturbances associated with the development of the Hamersley Surface. It was found that, between the base of the Dales Gorge Member and $\mathrm{BIF}_{11}$ (the top bands are even more disturbed), only the following units are exposed completely somewhere in the west bank slopes and can be measured with confidence: $\mathrm{BIF}_{0}, \mathrm{~S}_{1}, \mathrm{BIF}_{1}, \mathrm{~S}_{2}, \mathrm{BIF}_{2}, \mathrm{BIF}_{6}, \mathrm{BIF}_{7}$, $\mathrm{BIF}_{\varepsilon}, \mathrm{BIF}_{11}$. All other linking units, and particularly within and on margins of $\mathrm{S}$ bands, are obscured in part by post depositional breccias (Fig. 2).

Fig. 3 illustrates the thicknesses of these measured macrobands compared to their analogues of the type section. The data indicate that, for these units, BIF macrobands are slightly thicker and S bands considerably thinner than those of the type section, suggesting less clastic or tuffaceous components. Thus isopachs, for the BIF portions only, would result in a radically different picture than the ones obtained by Trendall \& Blockley.

Trendall's components (op. cit. p. 128) pertaining to the satisfactory integration of his isopach evidence should be revised, possibly in favour of our »heterodox» interpretation. 


\section{References}

Anonymous (1975) Mt. Newman iron ore deposits. 25th I. G. C.-Guidebook.

Blockley, J. G., Trendall, A. F., de Laeter, J. R. and Libby, W. G. (1980) Two »anomalous» isochrons from the vicinity of Newman. West. Australia Geol. Surv. Ann. Rept. 1979, 93-96.

Bourn, R. and Jackson D. G. (1979) A generalised account of the Paraburdoo iron ore bodies. Australasian Inst. Mining Metall., Western Australia Conference, August 1979, 187-201.

Daniels, J. L. (1968) Turee Creek, Western Australia $1: 250,000$. Geol. Ser. Explan. Notes BMR Geol. Geophys.

- (1970) Wyloo, Western Australia 1:250,000. Geol. Ser. Explan, Notes BMR Geol. Geophys.

de la Hunty, L. E. (1964) Balfour Downs, Western Australia $1: 250,000$. Geol. Ser. Explan. Notes BMR Geol. Geophys.

- (1965) Mount Bruce, Western Australia $1: 250,000$. Geol. Ser. Explan. Notes BMR Geol. Geophys.

- (1969) Robertson, Western Australia 1 : 250,000. Geol. Ser. Explan. Notes BMR Geol. Geophys.

Ewers, W. E. and Morris, R. C. in the press. Studies on the Dales Gorge Member of the Brockman Iron Formation, Western Australia.

Fraser, A. A. (1976) Gravity provinces and their nomenclautre BMR Journ. Aust. Geol. Geophys., $1,350-352$.
Hickman, A. H. (1980) Lithological map and stratigraphic interpretation of the Pilbara Block. Scale $1: 1,000,000$. West. Australia Geol. Surv. Australia publ.

Horwitz, R. C. (1976) Two unrecorded basal sections in older Proterozoic rocks of Western Australia. CSIRO Division of Mineralogy Rept. FP 17.

- (1978) The Lower Proterozoic of the Wyloo anticline. CSIRO Division of Mineralogy Rept. FP 20.

Horwitz, R. C. and Smith, R. E. (1978) Bridging the Yilgarn and Pilbara Blocks, Western Australia. Precambrian Res., 6, 293-322.

MacLeod, W. N. (1966) The geology and iron deposits of the Hamersley Range area. West. Australia Geol. Surv. Bull. 117.

Trendall, A. F. (1980) A progress review of the Hamersley Basin of Western Australia. Finland, Geol. Surv. Bull. 307, 113-131.

Trendall, A. F. and Blockley, J. G. (1968) Stratigraphy of the Dales Gorge Member of the Brockman Iron Formation, in the Precambrian Hamersley Group of Western Australia. West. Australia Geol. Surv. Ann. Rept. 1967, 48-53.

- (1970) The iron formations of the Precambrian Hamersley Group, Western Australia, with special reference to the associated crocidolite. West. Australia Geol. Surv. Bull. 119. 